\title{
ネビュライザー投与薬剤の抗原性の研究
}

\author{
石塚 洋一・鰐㴊 伸子

\section{Antigenicity of Drugs Administered Using a Nebulizer}

\author{
Yoichi Ishizuka and Nobuko Wanifuchi \\ (Teikyo University, Mizonokuchi Hospital)
}

\begin{abstract}
An experimental study was performed to evaluate the antigenicity of some drugs used in nebulization administered to guinea pigs.

Male Hartley guinea pigs were housed in an acrylic chamber and drugs such as DKB and histamine-added $\gamma$ globulin solutions were sprayed into the chamber using an ultrasonic nebulizer. The medication were administered for a maximum duration of 4 weeks. As antigenicity tests, the Schultz-Dale reaction and passive cutaneous anaphylaxis test (PCA test) were evaluated. After the aerosol exposure, all animals tested were negative for the Schultz-Dale reaction or the PCA test. On the other hand, after aerosol administration of ovalbumin solution for 2 or 4 weeks, the animals tested showed positive results in the two tests. These findings suggest that nebulizer therapy with histamine-added $r$ globulin or DKB solutions shows no antigenicity, but attention should be paid in the use of nebulizer therapy in other drugs with high antigenicity.
\end{abstract}

Key words: nebulizer, antigenicity, Schultz-Dale reaction, PCA test, guinea pig

\section{はじめに}

ネビュライザー療法は，日常臨床で広く用い られている局所療法の一つである。本療法は非 侵襲性に行われるために患者側に対する負担が 少なく，医師の指導と監視の下に手軽にかつ比 較的安全に行らことができる利点をもっている。 しかし，これまでにもときに局所的・全身的副 作用の報告もあり1)，投与方法や薬剂選択には 十分な注意を払う必要がある。また，比較的長 期に本療法が用いられるケースもあり，そこで 問題になるのが局所粘膜の損傷, 細菌叢の変化 とともに投与薬剤による感作である.

今回われわれは,ネビュライザー療法による 投与薬剤のI 型アレルギー反応若起の可能性に
ついて，モルモットを用いた基礎的検討を行っ たので報告する．

\section{対象および方法}

Hartley 系雄性モルモット (平均体重 $400 \mathrm{~g}$ ) を用いて実験を行った。モルモットをアクリル 製ケース $(30 \times 47 \times 30 \mathrm{~cm})$ に収容し，ケース上 面の吸気口 (内径 $18 \mathrm{~cm})$ よりヶース内にエチ レン酢酸ビニール樹脂製ホース (内径 $22 \mathrm{~mm}$ ) を介して各種薬剤のネビュライザーを行った． ケース内の霧化薬物を均一化するためのモー ターファン（直径 $11 \mathrm{~cm}$ )を上面に取り付けた (図 1 ).ネビュライザーは超音波ネビュライザー (ME-U 10 B，オムロン)を使用し，薬物を約 $1.6 \mathrm{ml} /$ 分の霧化速度で 1 回当り 10 分間噴霧し 
た。噴霧群の例数は 1 群 4 匹とした。

1. 噴霧薬凨と投与方法

1 ) $0.0313 \%$ 硫酸ジベカシン(以下 DKB と 略す)

DKB を生理食塩液で希釈し，1日 8 回，最 高 4 週間まで連続投与した。DKB はモルモッ 卜 1 匹当りの 1 回噴霧量が $1.25 \mathrm{mg}$ となり, 日常臨床で用いている成人 $(60 \mathrm{~kg})$ に対寸る 1 日 1 回当りの噴霧量を $5 \mathrm{mg}$ として，モルモッ 卜の体重を $400 \mathrm{~g}$ とした時の体重換算では40倍 に相当する.

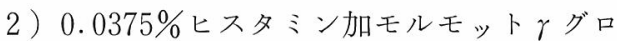
ブリン(以下 $\gamma \mathrm{G} 1$ と略す)

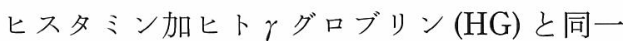
組成，すなわち 酸ヒスタミン $0.15 \mu \mathrm{g}$ を含有するように，モル モット血清 $\gamma$ グロブリン (Miles) と二塩酸ヒス タミンを混合したものをとスタミン加ヒト ケグ ロブリンのモデルとして用いた， $\gamma \mathrm{Gl}$ を生理食 塩液で希橎し，1日 8 回，最高 4 週間まで連続 投与を行った。 $\gamma \mathrm{Gl}$ はモルモット 1 匹当りの 1 回噴霧量は $1.5 \mathrm{mg}$ で，これは日常臨床で用い ている成人 $(60 \mathrm{~kg})$ 飞対する 1 日 1 回当りの $\mathrm{HG}$ 噴霧量を $6 \mathrm{mg}\left(\mathrm{HG} \frac{1}{2}\right.$ バイアル)とすると, モルモットの体重を $400 \mathrm{~g}$ とした時の体重換算 では40倍に相当する。

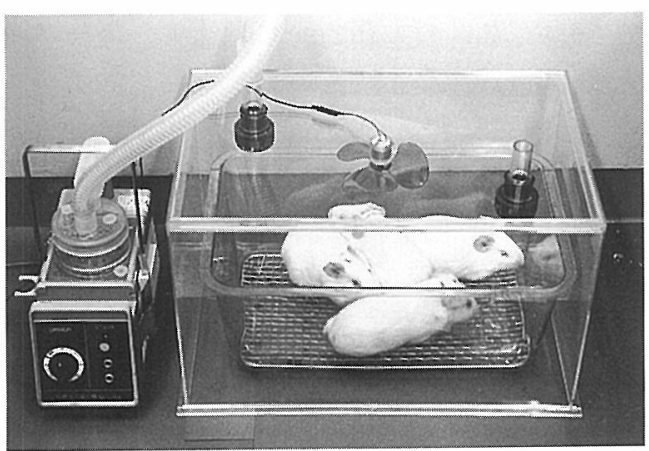

図1 モルモットに超音波ネビュライザーを 介乙て薬䨩投与を行う実験装置
3) $0.0375 \%$ 卵白アルブミン(以下 OA と略 寸)

抗原性試験の陽性対照薬として, 卵白アルブ ミンを生理食塩液で希釈し，1日 8 回，最高 4 週間まで連続投与を行った。

4) 生理食塩液

抗原性試験の対照薬として，1日8回，最高 4 週間まで連続投与を行った。

\section{2 . 抗原性試験}

以下のよらな 2 種類の抗原性試験を行った.

\section{1) Schultz-Dale 反応}

Schultz-Dale 反応は，アナフィラキシー反応 により，平滑筋が収縮する現象を用いた抗原性 試験であり，摘出回腸の収縮の有無から判定す る.

ネビュライザー最終投与後のモルモットを放 血致死させ, 回腸を直ちに摘出した後, 液温 37 ${ }^{\circ} \mathrm{C} ， 95 \% \mathrm{O}_{2}+5 \% \mathrm{CO}_{2}$ 飽和 Tyrode 液を満し たマグヌス管(容量 $2 \mathrm{ml}$ ) 内に懸垂し，薬物に よる等張性収縮をアイソトニック・トランスデ ューサ (TD-112S，日本光電)を介して記録した. 初めに塩化アセチルコリン(オビソート ${ }^{\circledR}$ : base 換算で $\left.10^{-6} \mathrm{M}\right)$ を反復作用させて回腸の 収縮高が一定した後, challenge 抗原として被 検薬 $\left(10^{-5} \mathrm{~g} / \mathrm{ml}\right)$ を添加して回腸の収縮の有無 を観察した. 観察終了後, 再度塩化アセチルコ リンを作用させて回腸の収縮高が被検薬添加前 と同一であることを確認した。

生理食塩液噴霧群には被検薬として, DKB, rGl，ＯA を添加した．DKB 噴霧群には DKB を， $\gamma \mathrm{G} 1$ 噴霧群には $\gamma \mathrm{G}$ を，OA噴霧群には OAを添加した。

Schultz-Dale 反応を施行した時期は，各種薬 剂の噴霧 1 週間後, 2 週間後, 4 週間後の 3 回 である。

2) 同種皮膚アナフィラキシー反応試験 (passive cutaneous anaphylaxis reaction test，以下 PCA test と略す)

PCA test は抗原抗体反応の結果生じる, 漏 出色素の有無により判定する. 
剪毛した未処置モルモットの背部に生理食塩 液， $\mathrm{DKB} ， \gamma \mathrm{Gl}, \mathrm{OA}$ のネビュライザー投与後 のモルモットより採取した血清 $0.1 \mathrm{ml}$ を皮内 注射し受動感作した。感作 4 時間後に $5 \mathrm{mg}$ の 抗原(生理食塩液, $\mathrm{DKB}, \gamma \mathrm{Gl}$ )を含む $1 \%$ エバ ンスブルー生理食塩液 $1 \mathrm{ml}$ を前肢静脈内に投 与して，PCA 反応を誘発した．抗原投与 30 分 後に断頭屠殺し，PCA 反応より生じた色素漏 出を観察した。判定はわずかでも色素の漏出が 認められた場合には陽性とした。

PCA test は, 各種薬剤噴霧の 1 週間後, 2 週間後, 4 週間後の 3 回行った.

\section{結果}

1. Schultz-Dale 反応

図 2 に, Schultz-Dale 反応による回腸の収縮 を記録した結果を示した。 4 週間噴霧群の例の

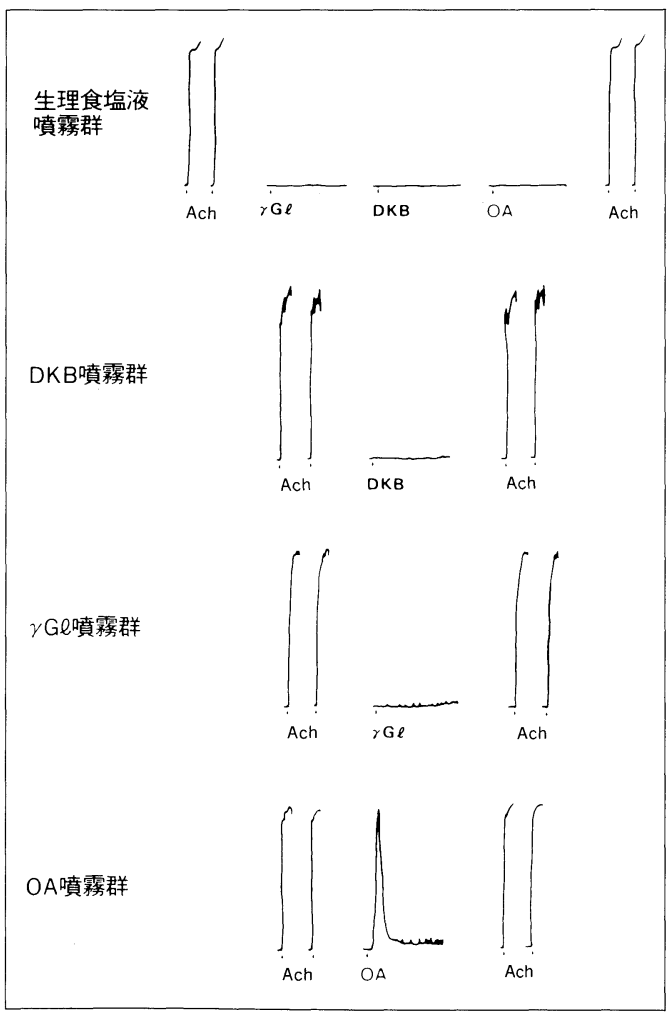

図 2 モルモット摘出回腸における Schultz-Dale 反応 $(4$ 週間噴霧)
み示したが，生理食塩液噴霧群に $\gamma \mathrm{Gl} ， \mathrm{DKB}$, $\mathrm{OA}$ を，DKB 噴霧群に DKB を， $\gamma \mathrm{Gl}$ 噴霧群に $\gamma \mathrm{Gl}$ を添加しても回腸の収縮は認められなかっ た。 OA 噴霧群に OA を添加すると回腸の収縮 を認めた。な扮すべての噴霧群に抋いて，被検 薬添加前後に塩化アセチルコリン (Ach) を添加 すると回腸の収縮が一定してみられた。

Schultz-Dale 反応による 1 週間後, 2 週間後, 4 週間後の反応陽性モルモット数を各群ごとに 表 1 亿示した。生理食塩液噴霧群, DKB 噴霧 群, $\gamma \mathrm{Gl}$ 噴霧群では, 1 週間後, 2 週間後, 4 週間後とも，反応陽性モルモットは全くみられ なかった。一方， OA 噴霧群では 1 週間後は全 例が陽性反応を示さなかったが， 2 週間後，4 週間後では 4 匹すべてが反応陽性であった.

2. PCA test

図 3 に, PCA test によるモルモット背部の 色素漏出を challenge 抗原別に示した。 4 週間 噴霧群の例の久示したが, challenge 抗原とし て $\gamma \mathrm{Gl}$ ， DKB を用いても，各群ともに色素漏 出を認めない. challenge 抗原として OA 用 いると, 生理食塩液噴霧群, DKB 噴霧群, $\gamma \mathrm{G} 1$ 噴霧群に対してそれぞれ色素漏出を認めな かったが，OA 噴霧群に対してそれぞれ色素漏 出を認めた。

PCA test $の 1$ 週間後, 2 週間後, 4 週間後 で，生理食塩液噴霧群， $\mathrm{DKB}$ 噴霧群， $\gamma \mathrm{G} 1$ 噴

表 1 Schultz-Dale 反応による回腸収縮 モルモット数の割合

\begin{tabular}{|c|c|c|c|}
\hline $\begin{array}{l}\text { 薬 剂 } \\
\text { 噴霧期間 } \\
\end{array}$ & 1 週間 & 2 週間 & 4 週間 \\
\hline 生理食塩液 & $0 / 4$ & $0 / 4$ & $0 / 4$ \\
\hline DKB & $0 / 4$ & $0 / 4$ & $0 / 4$ \\
\hline$\gamma \mathrm{G} \ell$ & $0 / 4$ & $0 / 4$ & $0 / 4$ \\
\hline$O A$ & $0 / 4$ & $4 / 4$ & $4 / 4$ \\
\hline
\end{tabular}




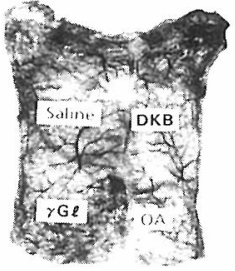

$\gamma \mathrm{G} \ell$

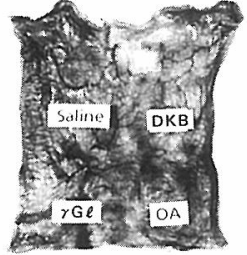

DKB

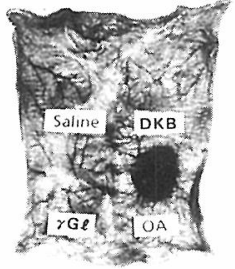

OA

図 3 challenge 抗原別にみた PCA test そよるモルモット背部の色素漏出

表 2 PCA test による反応陽性モルモット 数の割合

\begin{tabular}{|c|c|c|c|}
\hline $\begin{array}{l}\text { 噴霧期間 } \\
\text { 薬 郕 }\end{array}$ & 1 週間 & 2 週間 & 4 週間 \\
\hline 生理食塩液 & $0 / 4$ & $0 / 4$ & $0 / 4$ \\
\hline DKB & $0 / 4$ & $0 / 4$ & $0 / 4$ \\
\hline$\gamma \mathrm{G} \ell$ & $0 / 4$ & $0 / 4$ & $0 / 4$ \\
\hline$O A$ & $0 / 4$ & $4 / 4$ & $4 / 4$ \\
\hline
\end{tabular}

霧群, OA 噴霧群の色素漏出を認めたモルモッ 卜数を表 2 に示した。生理食塩液噴霧群, DKB 噴霧群, $\gamma \mathrm{G} 1$ 噴霧群では, 1 週間後, 2 週間後, 4 週間後とも色素漏出モルモットは全 くみられなかった。 OA 噴霧群は， 1 週間後で は色素漏出は全くみられなかったが，2 週間後， 4 週間後には 4 匹すべてに色素漏出がみられた。

\section{考察}

ネビュライザー療法は霧化器を用いて薬剤を 微粒子すなわちエアロゾル化し，経鼻あるいは 経気道的に吸入させて, 直接的に病巣に到達さ せる局所療法であり，古くから耳鼻咽喉科領域 に执いて繁用されている治療法の一つである. その対象疾患としては鼻アレルギーなどのアレ ルギー性疾患あるいは咽喉頭炎や副鼻腔炎など の炎症性疾患が主なものである。そのためネビ ュライザー療法に抗生物質, 抗アレルギー剂, ステロイド剤が多く使用されている。そして，
これら薬剂の使用に当って注意しなければなら ない点は当然のことながら副作用の防止である。 なかでも，薬剤によるアレルギー性素因をるつ 患者に対する感作や組織に対する障害について は特に留意しなければならない。

ネビュライザー療法の組織障害性については, われわれが行った動物実験 ${ }^{2)}$ の結果から，現在 臨床に使用されている薬剂では, 長期噴霧によ っても光顕や電顕像に軽微な変化しかみられな かった。したがって，ネビュライザ一療法は形 態学的な面からの安全性に関しては, 一部の薬 剤の検討結果からであるが問題ないものと推察 された。

しかし，われわれが行ったネビュライザー療 法に関するアンケート調查3)では, ネビュライ ザーを実施している104名の耳鼻咽喉科医の中 で，39件の副作用の報告がみられ，薬剤感作に よると思われる死亡例が 1 件含まれていた。

今回, われわれはネビュライザー療法の副作 用の中でも薬剤による過敏性反応の発現の危険 性に注目して, 抗生物質 (DKB) あるいは抗了 レルギー剤(ヒスタミン加 $\gamma$ グロブリン)を, 薬 剂に対する感受性の比較的高いモルモットに臨 床での使用方法に近い形で投与し，投与薬剤の 抗原性について検討した。すなわらとトと同様 にネビュライザーを用いて経鼻的に吸入させ， 薬剤感作によるアレルギー反応の発現の有無に ついて検討した。薬剤感作を観察するため, Schultz-Dale 反応とPCA testによる 2 種類の 抗原性試験を行った。 
Schultz-Dale 反応は, 感作が終了した動物に おける即時型アレルギー反応を感作動物の摘出 平滑筋において若起せしめるものであり，薬物 の抗原性の検出反応として利用されている.

PCA test は，動物の皮内に抗血清を投与し， 局所皮内の好塩基球や肥満細胞を受動的に感作 し, 一定時間後に抗原と色素を静注し, 抗原一 抗体反応の結果引き扣こされたこれら細胞から の chemical mediator の遊離に上る局所毛細血 管の透過性元進による漏出色素の程度を測定し た定量的な研究により確立された。この反応も 薬剤の抗原性を検討する方法の一つである.

DKB， $\gamma \mathrm{Gl}$ ，生理食塩液を最高 4 週間連続し て噴霧したが，Schultz-Dale 反応，PCA test ともに薬剤による感作を示す陽性反応はすべて のモルモットにみられなかった。すなわち，い ずれの抗原性試験に括いても DKB， $\gamma \mathrm{Gl}$ に対 するアナフィラキシー性抗体 (IgE, IgG) は, 今回設定した噴霧期間からは検出することが出 来なかった．今回のモルモット 1 匹当りの薬剤 噴霧量は臨床で使用されている量の 40 倍に相当 し，大量に噴霧したことになるが，それにも関 わらずアナフィラキシー性抗体が産生されなか ったことより, 臨床使用に際して問題となるア ナフィラキシー症状などの副作用の発現におい

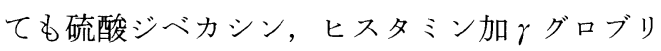
ンのネビュライザー療法は安全性の高い治療法 と考觉られた。

DKBについては，PCA testを用いた動物実 験から，アレルギー反応を起こす危険性の少な い抗生物質であることが報告4)されて拈り，わ れわれの結果と一致していた。

一方, 陽性対照薬として用いた卵白アルブミ ンを噴霧したモルモットは, 噴霧開始 2 週間後 にすでに Schultz-Dale 反応拉よび PCA test と も陽性反応が全例に認められた。卵白アルブミ ンは, 一般的に強い抗原性を示すタンパク質抗 原として種々のアレルギー実験に使用されてい る、ヒトでのネビュライザー療法による抗生剤 の血中濃度は, 同じ薬剤の静注あるいは筋注の
血中濃度に比較すると $\frac{1}{40 \sim 50}$ と非常に微量で ある. 今回行ったモルモットにネビュライザー を用いて投与された卵白アルブミンも体内に取 り込まれた量は少ないものと推察されるが，抗 原性試験で陽性反応が認められた。この結果か ら, 臨床に执いて, 抗原性の強い薬剤をネビュ ライザー療法のような局所療法で用いることに より，生体を感作する可能性が十分にあること が示唆された。

抗原に対する免疫応答の程度は, 動物間に相 違があるため, モルモットによる安全性がヒト にも同様な結果と考光るには問題な点も含まれ ている.

今回の動物実験による基礎的な検討結果では, 現在臨床に用いられている硫酸ジベカシンやと

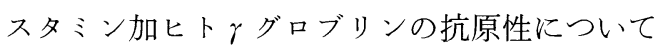
は，今回検討した投与量や投与期間からは I 型 アレルギー反応を炭起しらるといら陽性所見は 得られなかった。しかし，ヒトに抗原性の強い 薬剂をネビュライザー療法により局所投与する 場合に括いては，薬剤感作の危険性に注意を払 らとともに，アレルギー素因を有する患者への ネビュライザー療法に扣いては副作用を念頭に 敃いた使用が望まれる。

\section{まとめ}

ネビュライザー療法による投与薬剤の抗原性 について，モルモットを用いた基礎的検討を行 い次のよらな結果を得た。

1) 硫酸ジベカシン，ヒスタミン加モルモッ トケグロブリンを最高 4 週間投与したが， Schultz-Dale 反応, PCA test ともに，すべて のモルモットに陽性反応はみられなかった。

2 )卵白アルブミンでは, 投与 2 週間後, 投 与 4 週間後のすべてのモルモットに SchultzDale 反応, PCA test ともに陽性反応が認めら れた。

稿を終わるに臨み, ご助言をいただいた帝京大学 溝口病院小坚科新保敏和助教授に感謝するとともに, 本研究にご協力いただいた日本臟器生物活性科学研 究所に深謝いたします。 
本論文の要旨は，第91回日本耳鼻咽喉科学会総会 に扮いて報告した。

\section{文献}

1）坂倉康夫, 谷口 強 : ネビュライザー療法にと もなら副作用について.耳喉 52 : 99〜 104, 1980.

2）石塚洋一：ネビュライザー療法の安全性と実施 上の留意点. 耳展 32 : 485 494, 1989.

3）石塚洋一, 大藏眞一, 秋元淑子, 他：慢性副鼻 腔炎のネビュライザー療法の現状.耳鼻臨床
$83: 1813 \sim 1821,1990$.

4）塩田 洋, 大串淳子, 藤田善史：アミノ配糖体 系抗生物質ジベカシン $(\mathrm{DKB})$ 点眼液の抗原性 について. 日眼会誌 $85: 1492 \sim 1496,1981$.

$$
\left.\begin{array}{l}
\text { 原稿受付 : 平成 } 3 \text { 年 } 5 \text { 月 } 29 \text { 日 } \\
\text { 原稿採択 : 平成 } 3 \text { 年 } 8 \text { 月 } 9 \text { 日 } \\
\text { 別刷請求先 : 石塚洋一 } \\
\text { 干 } 213 \text { 川崎市高津区溝口 } 74 \\
\text { 帝京大学医学部附属溝口病院耳鼻咽喉科 }
\end{array}\right)
$$

